\title{
Hydrochemical disturbances measured in groundwater during the construction and operation of a large-scale underground facility in deep crystalline rock in Japan
}

\author{
Teruki Iwatsuki $^{1} \cdot$ Hiroki Hagiwara $^{2} \cdot$ Kazuaki Ohmori $^{1} \cdot$ Takashi Munemoto $^{1} \cdot$ \\ Hironori Onoe ${ }^{1}$
}

Received: 7 July 2014 / Accepted: 22 March 2015/Published online: 8 April 2015

(c) The Author(s) 2015. This article is published with open access at Springerlink.com

\begin{abstract}
Changes in the hydrochemical conditions of groundwater were evaluated following the construction of a large-scale underground facility at the Mizunami Underground Research Laboratory (MIU), Japan. The facility was constructed to a depth of $500 \mathrm{~m}$ in sedimentary and granitic rocks. Drawdown of the groundwater level in the range of several tens to hundreds of meters was observed up to hundreds of meters away from the shafts during the first ten years of facility construction and operation. Subsequent changes in groundwater chemistry occurred due to upconing of high-salinity groundwater from the deepest part of the shaft and the infiltration of low-salinity shallow groundwater. We predict that future deep groundwater chemistry in the vicinity of the MIU facility will resemble that of the present-day shallow groundwater. Multivariate statistical analysis provides fundamental insights into such a site. We found that the extent of hydrochemical variability related to MIU construction and operation was dependent on the distance from the facility shafts and galleries and on hydrogeological compartmentalization resulting from lithological boundaries (such as permeable conglomerates vs. more compact lithological units) and other features (such as faults or clay layers). We conclude
\end{abstract}

Electronic supplementary material The online version of this article (doi:10.1007/s12665-015-4337-3) contains supplementary material, which is available to authorized users.

Teruki Iwatsuki

iwatsuki.teruki@jaea.go.jp

1 Tono Geoscience Center, Japan Atomic Energy Agency, 1-64, Yamanouchi, Akiyo, Mizunami, Gifu 509-6132, Japan

2 Fukushima Environmental Safety Center, Japan Atomic Energy Agency, 1-29, Okitama, Fukushima-shi, Fukushima 960-8034, Japan that hydrochemical impact assessment of groundwater in low-permeability rock is essential prior to the construction of such a facility. This should include characterization of hydrogeological structures and compartments to propose suitable location of shafts and galleries.

Keywords Crystalline rocks - Groundwater monitoring · Hydrochemistry · Underground laboratory experiments

\section{Introduction}

The characterization of hydrochemical features and processes in the bedrock of underground facilities is important for the engineering and geosciences fields. It has significant implications for the geological disposal of high-level radioactive waste (HLW) originating from nuclear power plants (Banwart and Gustafsson 1994; Gascoyne et al. 1995; Laaksoharju et al. 1999; Thury and Bossart 1999; Flint et al. 2001; Cai and Kaiser 2005; Martinez-Landa and Carrera 2005, 2006; Joyce et al. 2010), long-term engineering and environmental effects of tunnels (Ii and Kagami 1997; Sato et al. 2000; Cesano et al. 2000; Vales et al. 2004; Yang et al. 2008; Font-Capo et al. 2012), and following the construction of underground storage facilities and mines (Younger 2000; Maejima et al. 2003; Lee et al. 2003; Bauer et al. 2013; Lee et al. 2014). The selection of a disposal site for HLW, for instance, takes into consideration the geological environment at depths of hundreds of meters assessed by various surface-based investigations. However, the construction and operation of a large underground facility, such as an HLW repository, could lead to changes in the geological environment on the timescale of tens to hundreds of years, which impacts the suitability of the selected disposal site. For example, previous studies 
in the Aspo Hard Rock Laboratory, Sweden, showed that hydraulic disturbances occurred in the crystalline rock (Grenier et al. 2009), leading to a drawdown of the groundwater level by tens of meters and the penetration of tritium containing groundwater into the laboratory (Laaksoharju et al. 1999; Mahara et al. 2001). Another case of groundwater level drawdown was observed at the Underground Research Laboratory in Manitoba, Canada, where $60 \mathrm{~m}$ drawdown of the groundwater level occurred around two shafts in the Lac du Bonnet granite batholith over a 25-year period of construction and operation at a depth of more than $420 \mathrm{~m}$. Groundwater inflow along fractures and faults intersected by the shafts leads to the mixing of distinctly different saline groundwaters and significantly changes the water chemistry (Priyanto et al. 2014).

These previous studies indicate that the construction and operation of an underground facility lead to changes in the hydraulic environment. Excavation of tunnels allows discharge of groundwater from surrounding rock depending on the hydrogeological properties of the host rock. Possible impacts are drawdown of the groundwater level, infiltration of near-surface waters to deeper depths, and upconing of relatively deeper groundwater, which leads to changes in groundwater chemistry around the facility. The magnitude of groundwater disturbances depends on the facility design and layout and hydrogeological properties (e.g., permeability) of the surrounding rock (Domènech et al. 2006; Stober and Bucher 2007). However, there have been few similar studies that examine environmental impact on groundwater flow and chemistry due to the construction and operation of large-scale underground facilities in deep underground. Therefore, a study of this generic phenomena and the extent of groundwater chemistry disturbance around various underground facilities are required. This should encompass hydrogeological conditions determined by long-term monitoring during the construction, operation, and post-closure of the facility to assess the current safety assessments of HLW disposal.

The Mizunami Underground Research Laboratory (MIU) project at Mizunami, Japan, is being conducted by the Japan Atomic Energy Agency (JAEA) to establish general techniques for the investigation, analysis, and assessment of construction in deep crystalline rock. A facility with two shafts and galleries was constructed up to $500 \mathrm{~m}$ depth in sedimentary rocks and basement granite. These geological strata contain a variety of hydrogeological characteristics such as low-permeable zones, faults and fractures. In this study, we identify the hydrochemical changes in groundwater observed in various hydrogeological environments at this site in response to 10 years of construction and operation of the facility. Moreover, we aim to characterize how the construction of such underground facilities should reduce their environmental impact by taking into account the above-mentioned hydrogeological properties.

\section{Hydrogeology and baseline groundwater chemistry prior to the construction of the MIU facility}

The undisturbed baseline conditions of the geological environment (geology, hydrogeological structures, hydraulic conditions, and groundwater chemistry) prior to MIU construction were characterized by compiling existing information obtained from geological and geophysical surveys and new borehole investigations including hydraulic tests, groundwater sampling in boreholes (MSB-1, 2, 3, 4: 100-200 m; MIZ-1: 1200 m; Fig. 1, Kumazaki et al. 2003; Metcalfe et al. 2003; Takeuchi et al. 2004; Iwatsuki et al. 2005; Saegusa and Matsuoka 2010).

At the MIU site, sedimentary rock (the Mizunami Group, 20-15 Ma, consisting of the Akeyo Formation, Hongo Formation, and Toki Lignite-bearing Formation) unconformably overlies Toki Granite (70 Ma). The middle and upper parts of the Mizunami Group consist of the Akeyo Formation (Fm) and Hongo Fm and are composed of siltstone-sandstone alternations, mudstones, and conglomerates. In contrast, the lower part of the Mizunami Group, the Toki Lignite-bearing Fm, consists of lignite-bearing fluvial deposits with basal conglomerate. Constituent minerals of the sedimentary rocks include quartz, plagioclase, K-feldspar, carbonate, and sulfide/sulfate minerals. Precipitation of Fe-oxy-hydroxides and dissolution textures of carbonate minerals are observed up to $60 \mathrm{~m}$ below ground level, suggesting low $\mathrm{pH}$ and oxidizing conditions in these shallow sedimentary rocks. The diagenetic clay mineral assemblage in the Mizunami Group is dominated by the smectite group (Utada 2003; Sasao et al. 2006).

The Toki granite has three rock facies grading from muscovite-biotite granite, hornblende-biotite granite, and biotite granite. The constituent minerals are quartz, plagioclase, K-feldspar, biotite, hornblende, muscovite, accessory minerals, and secondary minerals such as chlorite, calcite, and pyrite (Yuguchi et al. 2011, 2013). The granite was sometimes exposed to arial weathering, indicated by an observed weathering zone. The granite has, therefore, been divided into a weathered zone in the uppermost part, an upper highly fractured domain (UHFD), and a lower sparsely fractured domain (LSFD) (Fig. 1). The UHFD contains a low angle, highly fractured zone (LAFZ), and together with the LSFD extends to an estimated depth of $500 \mathrm{~m}$ within the Toki granite. Several large-scale faults with NW to NNW, NE, and EW strikes cut across the MIU site (Saegusa et al. 2003; Ohyama et al. 2008; Saegusa and Matsuoka 2010). 


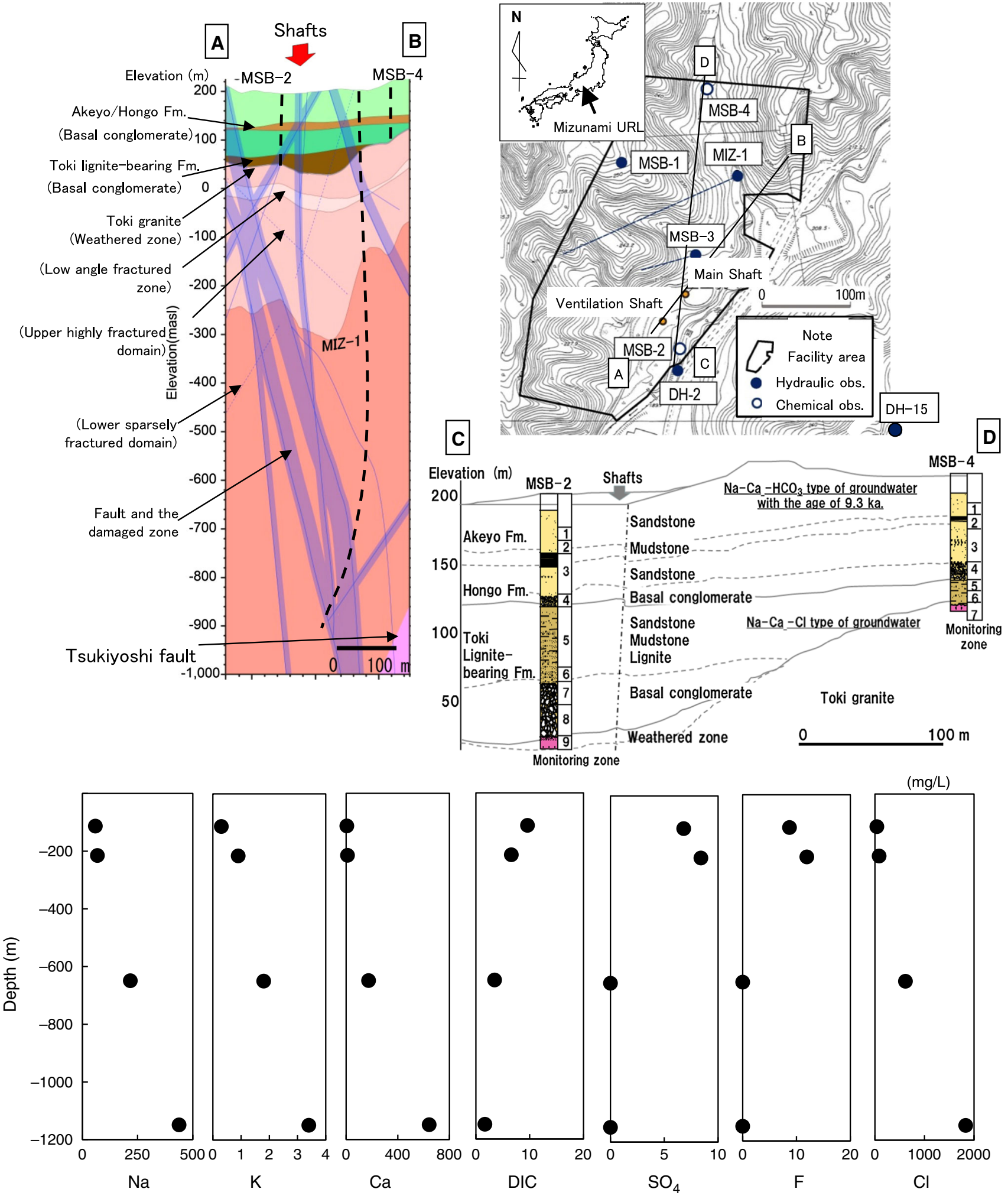

The error is within the range of circle.

Fig. 1 Geology and layout of monitoring boreholes at the ground surface, and groundwater chemistry in granite determined by borehole investigations at MIZ-1 prior to facility construction 
Cross-hole hydraulic testing (i.e., long-term pumping in MIZ-1 and monitoring in DH-2, DH-15, and MSB boreholes, as shown in Fig. 1) was conducted by Daimaru et al. (2010) and Onoe et al. (2011) to determine the hydrogeological structure around the MIU site. They showed that the dominant groundwater flow paths are in the basal conglomerates of the Akeyo/Hongo Fms and the Toki Lignite-bearing Fm. They also identified hydraulic boundaries due to the presence of clay layers (with relatively low hydraulic conductivity) throughout the sedimentary rock and some faults.

Hydraulic heads in the main part of Akeyo Fm are 30-50 $\mathrm{m}$ higher than those in the basal conglomerate of the deeper Hongo Fm, whereas chemically distinct groundwaters in the Akeyo Fm $\left(\mathrm{Na}-\mathrm{Ca}-\mathrm{HCO}_{3}\right.$ type), which are rich in silicon and sulfate ions, contrast with groundwater in the Toki Lignite-bearing Fm and the uppermost part of the granite ( $\mathrm{Na}-\mathrm{Ca}-\mathrm{Cl}$ type). These findings also indicate that the low-permeability clay layer in the Akeyo Fm and Hongo Fm is likely to act as a hydraulic barrier. The $\mathrm{Na}-$ $\mathrm{Ca}-\mathrm{HCO}_{3}$-type groundwater is believed to have originated as meteoric water with subsequent evolution due to waterrock interactions. The residence time of groundwater in the deeper part of the Akeyo and Hongo Fms is estimated to be approximately $9.3 \mathrm{ka}$ B.P. (Iwatsuki et al. 2005).

In the Toki granite, groundwater chemistry is dominated by $\mathrm{Na}-\mathrm{Ca}-\mathrm{Cl}$. Baseline chemical profiles at MIZ-1 borehole are shown in Fig. 1. It was found that the salinity of the groundwater generally increases with depth, whereas the concentrations of $\mathrm{SO}_{4}, \mathrm{~F}$, and DIC decrease to almost zero $\mathrm{mg} / \mathrm{L}$ with depth. Major solute ions such as $\mathrm{Na}, \mathrm{Ca}$, and $\mathrm{K}$ relate well with $\mathrm{Cl}$. Groundwater salinity at $1000 \mathrm{~m}$ depth in the granite in and around the MIU site is $2500 \mathrm{mg}^{-1}$ (about one tenth that of seawater); however, the origin and residence time of the deep saline groundwater are still unclear.

\section{Facility construction and hydrochemical monitoring methods}

After investigating the geology, rock strength, hydraulic conditions, and groundwater chemistry, the underground facility was constructed up to a depth of $500 \mathrm{~m}$ and completed by the end of March 2013. Figure 2 shows the layout of shafts and galleries of the MIU facility and monitoring boreholes drilled from the galleries. The design of the underground facility consists of main shaft $(6.5 \mathrm{~m}$ in diameter) and ventilation shaft (4.5 $\mathrm{m}$ in diameter). There are two Access/Research galleries, each at 300 and $500 \mathrm{~m}$ below ground level, and substages at $100 \mathrm{~m}$ depth between the two shafts. The length of " $300 \mathrm{~m}$ Access/Research Gallery" and "500 m Access/Research Gallery (North)" is about 100 and $150 \mathrm{~m}$, respectively. The shafts had been excavated by two $1.3-\mathrm{m}$ blasting and mucking cycles followed by the emplacement of a concrete liner in every $2.6 \mathrm{~m}$ section of the shaft (Shimono et al. 2004). Pre-excavation grouting of a water-conducting fracture zone was performed at the depths of 191-251 m, 421-428 m, and $446-453 \mathrm{~m}$ in the ventilation shaft and at $300 \mathrm{~m}$ Access/ Research Gallery. Since the start of the excavation in 2003, the shafts have been excavated to a total depth of $500 \mathrm{~m}$. From October 2005 to February 2006, when the shafts had been excavated to $180 \mathrm{~m}$ depth (uppermost part of granite), groundwater discharge from the shafts had to be reduced while the effluent treatment facility was being expanded. As a result, the shafts were temporarily flooded by groundwater up to $50 \mathrm{~m}$ below ground level.

Water collection rings (WR) were placed every $25 \mathrm{~m}$ in the shafts to direct water inflow and reduce water pressure on the concrete lining. The WR system is also available to observe the inflow rate and collect groundwater samples at depth. Periodic monitoring of groundwater pressure and chemistry was conducted in monitoring boreholes from the surface (MSB-2, MSB-4, and MIZ-1 in Fig. 1), galleries (07MI07, 09MI20, 09MI21, 10MI26, 12MI33 in Fig. 2), and in the WRs (41 sampling points) to monitor the hydrochemical disturbance caused by facility construction and operation. The monitoring zones of each borehole and the location of WRs are presented in Table 1. Groundwater was collected under closed-system conditions using either: (a) a multi-level groundwater monitoring system (Westbay MP system); (b) stand-pipe multi-packer system (Solexperts SPMP system); or (c) continuous hydrochemical monitoring system (JAEA CHM system). In each of these boreholes, uranine, amino G. acid, and sodium naphthionate were used as tracers, as a quality control measure, to ensure that water samples were not contaminated with residual drill fluid. The groundwater from WRs in contact with the concrete liner was collected under open-system conditions.

All water samples were filtered using $0.45-\mu \mathrm{m}$ membrane filters prior to chemical analyses. Tracer concentrations were measured by a fluorescence spectrophotometer (HITACHI F-3000) with a precision of $\pm 10 \%$. The concentrations of $\mathrm{Na}, \mathrm{K}, \mathrm{Ca}, \mathrm{Mg}, \mathrm{F}, \mathrm{Cl}$, and $\mathrm{SO}_{4}$ were analyzed by ion chromatography (Dionex ICS-1000). Water samples for total-Fe, $\mathrm{Si}, \mathrm{Al}$ were first adjusted to $\mathrm{pH} 2$ and then measured by inductively coupled plasma atomic emission spectrometry (ICP-AES; RIGAKU CIROS-Mark II). $\mathrm{Fe}^{2+}$, $\mathrm{S}^{2-}$, total carbon, and dissolved inorganic carbon (DIC) were analyzed by ultraviolet and visible light spectrophotometry (SHIMADZU UVmini-1240) and a TOC meter (Analytikjena multi-N/C 2100S) with a precision of $\pm 10 \% . \delta \mathrm{D}$ and $\delta^{18} \mathrm{O}$ were analyzed by mass spectrometry (Iso Prime) with a precision of $\pm 0.1 \%$. Tritium 


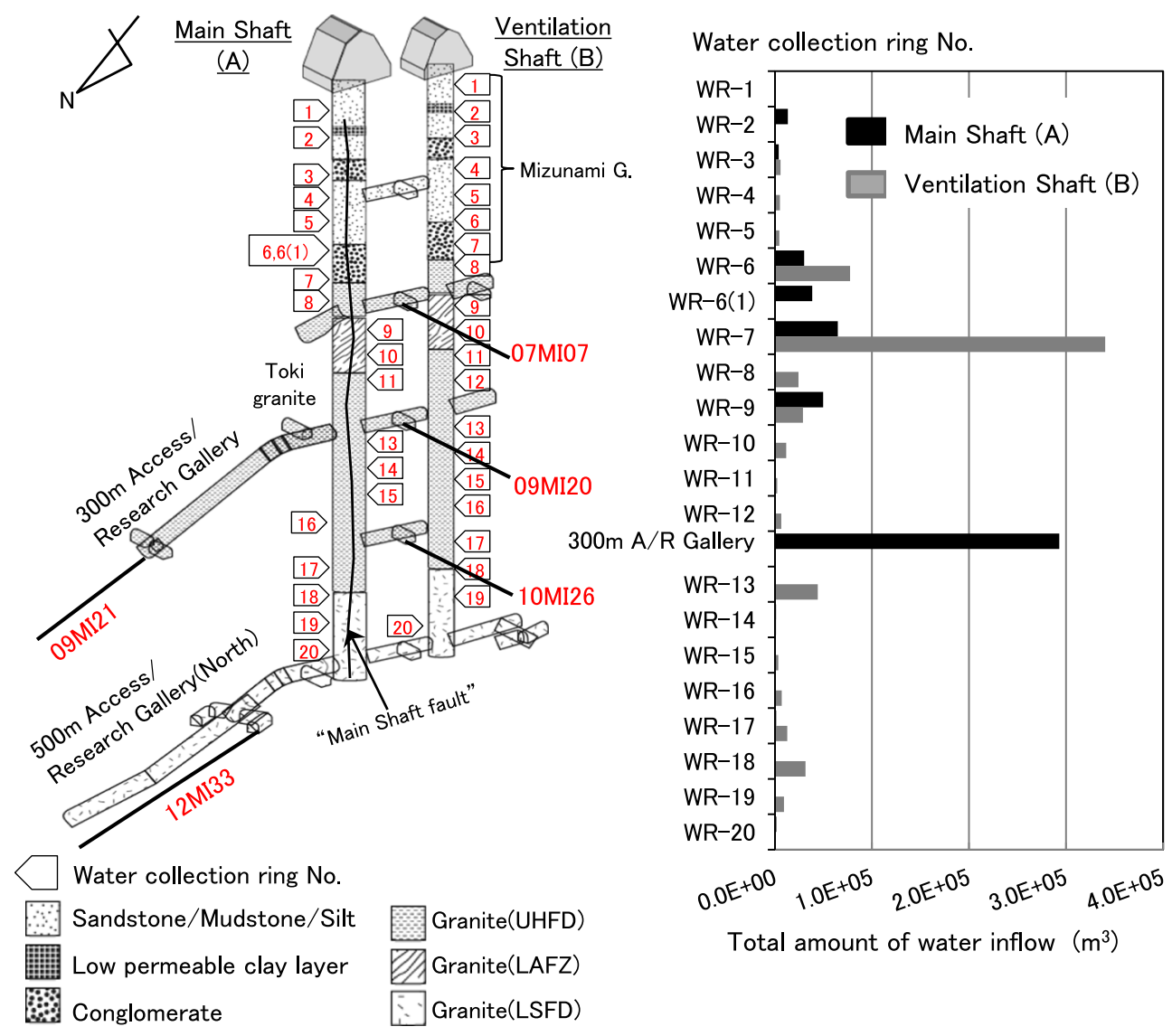

Fig. 2 Layout of water collection ring and hydrochemical monitoring boreholes in shafts and galleries, and total volume of groundwater inflow into the shafts and galleries up to 2013. Since the recent

excavation of the gallery, there are no data of inflow into the $500 \mathrm{~m}$ Access/Research Gallery

concentration was measured using a scintillation counter with a detection limit of $0.3 \mathrm{TU}$. Chlorofluorocarbons (CFCs) in the groundwater were collected by purging and trapping along a vacuum line system and analyzed by gas chromatography using an electron capture detector (SHIMADZU GC-8A) with a precision of $2 \%$. Multivariate numerical analysis principal component analysis (PCA) was conducted on all these data to characterize the chemical processes in this system.

\section{Results and discussion}

Environmental impact zones around the underground facility are classified into an Excavation Damaged Zone (EDZ) near the tunnel and an Excavation disturbed Zone (EdZ) comprising the EDZ and areas around the excavations (Olsson and Winberg 1996; Bossart et al. 2002; Tsang et al. 2005). In an EDZ, mechanical and hydrogeological properties of the rock were intensely fractured during excavation, and the chemical properties were also modified by shotcrete, grouting, and air circulation. Hydrochemistry of the groundwater in the EDZ is unlikely to recover to preconstruction values, even after the facility closes (Cai et al. 2001; Marty et al. 2009; Berner et al. 2013; Kosakowski and Berner 2013). In an EdZ, groundwater chemistry is possibly altered because of the mixing of chemically distinct waters induced by post-construction changes in the hydraulic properties of the host rock. However, hydraulic and chemical disturbances could possibly recover sometime after facility closure by re-saturation of the open space. This study focused on the hydraulic disturbance and induced chemical change in EdZ and their resulting hydrogeological structure.

\section{Hydraulic disturbances due to groundwater inflow in the shaft and gallery}

The geology intersected by the shafts is shown in Fig. 2 . The unconformity between Mizunami Group and Toki granite occurs at approximately $170 \mathrm{~m}$ depth in both the shafts. The boundary between the UHFD and LSFD in granite is considered to be at approximately $450-500 \mathrm{~m}$ depth. An NNW striking, vertical fault observed during 


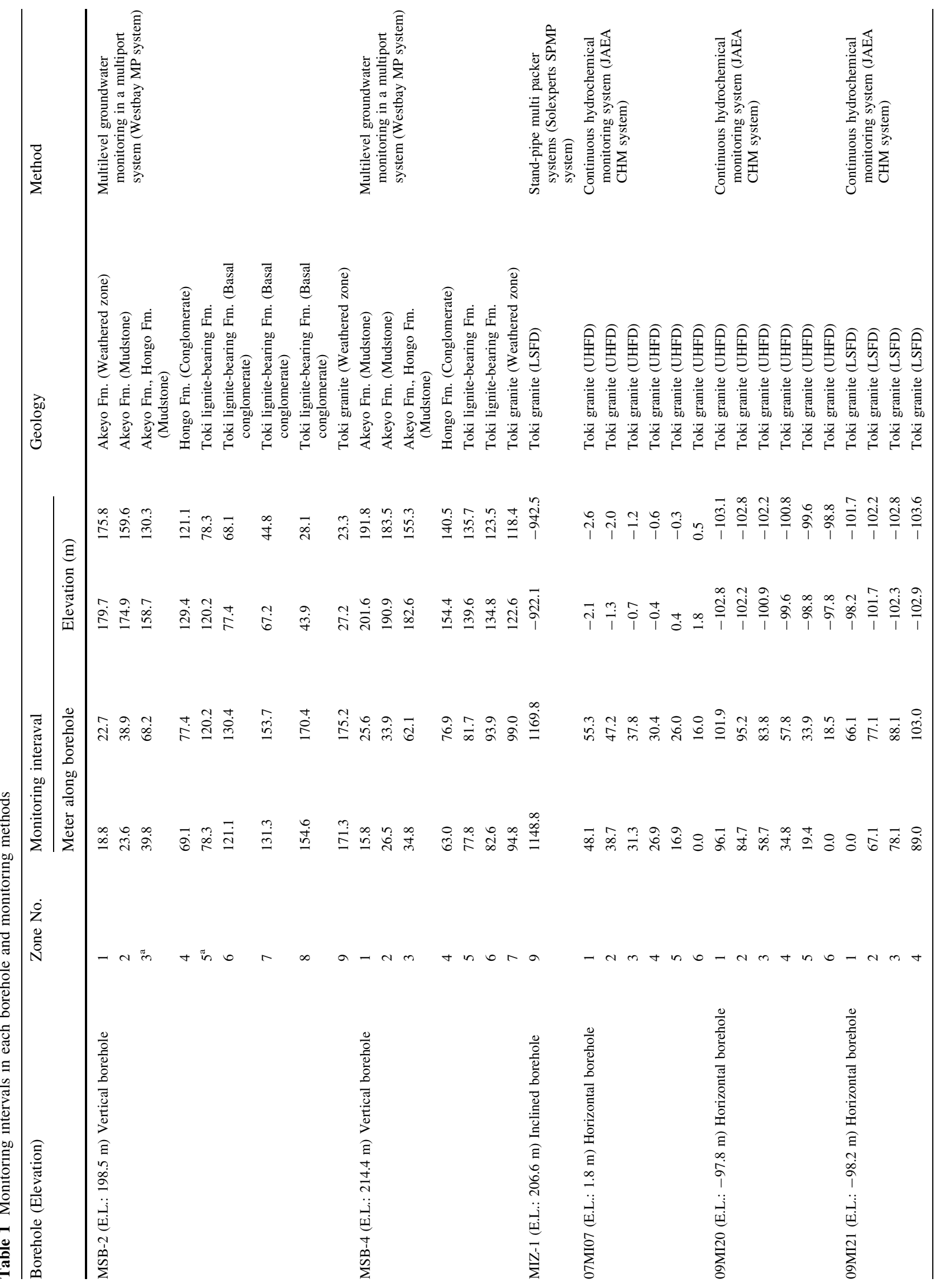




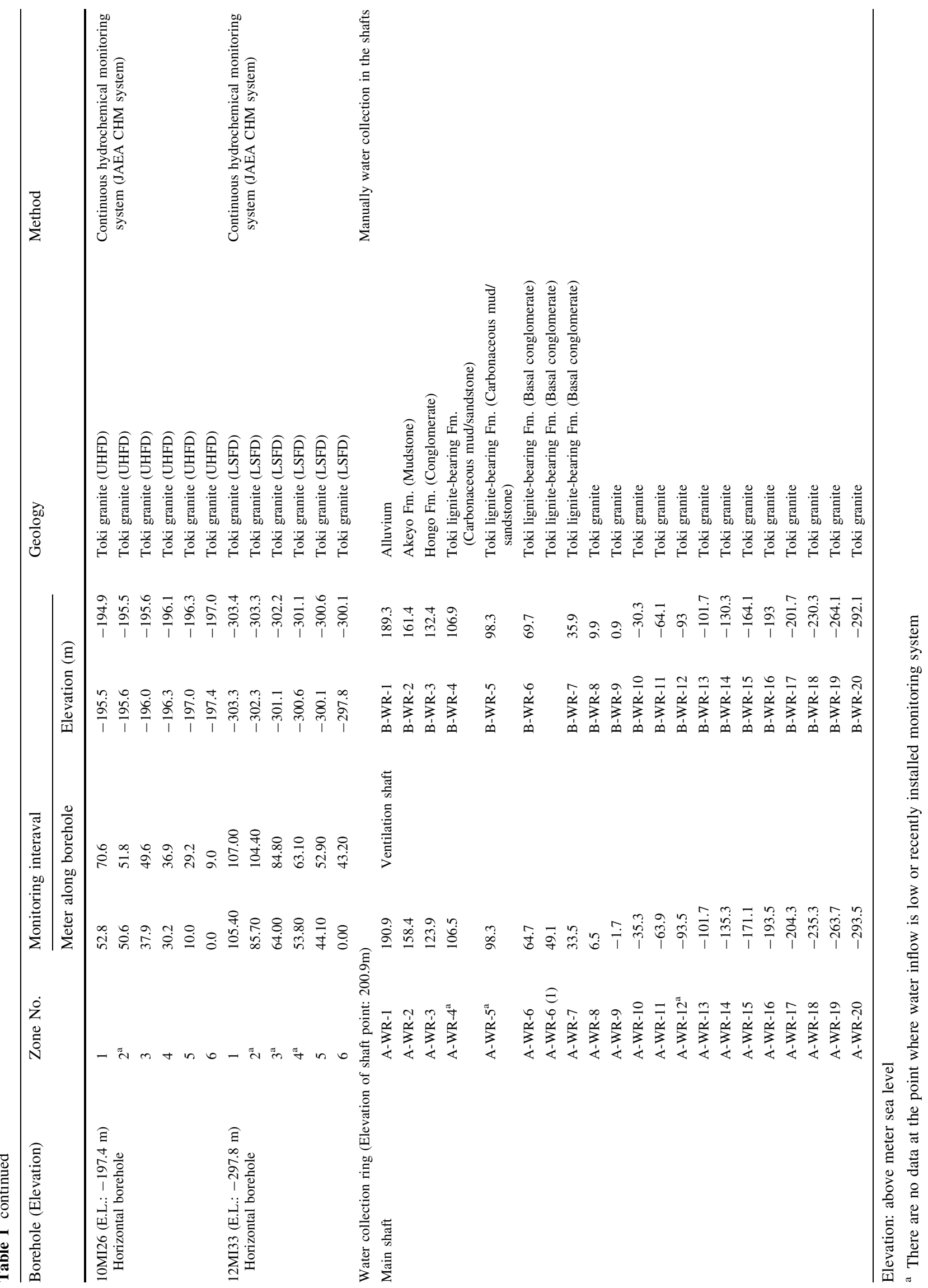


surface-based investigations is intersected by the main shaft. This fault, "the main shaft fault (MSF)," has an abundance of clay materials, which is the possible reason for the low hydraulic permeability of the fault. To evaluate hydrogeological properties, the cross-hole pumping test on both the sides of the MSF was conducted in boreholes penetrating the fault drilled from the $300 \mathrm{~m}$ Access/Research Gallery. The test indicated that the MSF acts as a flow barrier, normal to the fault plane, and may have reduced the degree of hydraulic disturbance during facility construction (Onoe et al. 2011). It also indicated that the granite has high hydraulic connectivity associated with water-conducting fractures and that a hydrogeological compartment is formed with low-permeability structures such as faults or clay layers in the sedimentary rock on both the sides of the MSF.

During shaft excavation, groundwater inflow into the excavations was in the order of hundreds of cubic meters a day. Figure 2 shows the total water inflow observed at each WR until 2013. The highest water inflow into the ventilation shaft of more than $3 \times 10^{5} \mathrm{~m}^{3}$ occurred from the conglomerate layer in the Toki Lignite-bearing Fm (WR7). The inflow at other depths in the sedimentary rock, mainly from sand-clay layers, was significantly low when compared with this conglomerate layer in the Toki Lignitebearing Fm. This conglomerate layer is most likely to be the dominant groundwater flow path in the sedimentary rock. The water inflow increased at the top of the granite becoming higher at WR-8 and WR-9, corresponding to weathered granite below the unconformity or LAFZ and at the $300 \mathrm{~m}$ Access/Research Gallery on the north side of the MSF. The connectivity and continuity of the fractures of LAFZ may be higher than those of UHFD other than LAFZ. The water inflow volume of approximately $3 \times 10^{5}$ $\mathrm{m}^{3}$ at the $300 \mathrm{~m}$ Access/Research Gallery is higher than that in both shafts in the granite due to differences in the encounter rate of excavations and fractures in granite. The statistical distribution of fracture dip in the granitic rock mass is currently unknown, but should be investigated to examine the excavation layout of low water inflow in future research. The water inflow volume into the main shaft tends to be small compared to flows into the ventilation shaft. Such differences are attributed to the low permeability of the MSF.

Hydraulic drawdown occurs at the borehole up to $500 \mathrm{~m}$ from the ventilation shaft (DH-15; Fig. 1, Daimaru et al. 2010). In this study, groundwater chemistry was observed at monitoring boreholes (MSB-2, MSB-4, MIZ-1, 07MI07, 09MI20, 09MI21, 10MI26, 12MI33; Figs. 1, 2) within an area of approximately $200 \mathrm{~m}$ away from shafts. Figure 3 shows the water pressure in each monitoring zone except for $12 \mathrm{MI} 33$, which was drilled recently. Water pressures in zones 1 and 2 of MSB-2, zones 1, 2, and 3 of MSB-4, and zone 3, 6, and 9 of MIZ-1 are less variable than those in zones 3-9 of MSB-2 and zones 4-7 of MSB-4, which clearly changed in response to shaft excavation. In the latter zones, water pressures temporally recovered during the shaft flooding (between October 2005 and February 2006) and have been subsequently decreasing ever since. Drawdown at 700-800 kPa and 300-400 kPa pressure from baseline conditions occurred at the boundary between the conglomerate layer and the weathered granite in MSB-2 (zones 6-9) and MSB-4 (zones 4-7), respectively. Water pressures in zones 4,6 , and 7 of MSB-4 were below atmospheric pressure. This suggests that the amount of water inflow from these geological formations to the shafts is larger than the groundwater recharge rates into these formations, and thus, the groundwater resource is depleting. These monitoring zones correspond to WRs with large inflow volumes [WR-6, WR-6(1) and WR-7; Figs. 1, 2]. The low-permeability clay layer in the sedimentary rock above acts as a hydraulic barrier and prevents the influence of shaft excavations on the shallow subsurface groundwater system.

Conversely, the boreholes drilled horizontally from galleries in granite were used to estimate drawdown with increasing lateral distance from the galleries. The monitoring results suggest that water pressures in the range of $100 \mathrm{~m}$ from the galleries decrease to $1.0-1.5 \mathrm{MPa}$ compared to the baseline conditions (Fig. 3). A similar decrease in water pressures is observed in all the monitoring zones in the 07MI07 borehole drilled from the $200 \mathrm{~m}$ stage. The water pressure in zone 6 near the gallery particularly decreases in 09MI20 and 10MI26 boreholes drilled from the $300 \mathrm{~m}$ and $400 \mathrm{~m}$ stages, respectively. Furthermore, the drawdowns in the 09MI21 borehole on the $300 \mathrm{~m}$ Access/Research Gallery, drilled on the north side of the MSF, are less than those in the 09MI20 borehole, and the drawdown is larger on the south side of the MSF compared to the north side. Any potential hydraulic impact due to the ventilation shaft is shielded by the MSF, from impacts on the north side of the fault.

Groundwater chemistry in the WRs is likely to vary due to water-cement interaction as a result of contact with the concrete liner. Incidentally, $\mathrm{Cl}$ is not susceptible to watermineral interaction, and variations in $\mathrm{Cl}$ concentration in WRs are shown in Fig. 4. $\mathrm{Cl}$ concentrations are higher in WR 6-10 in the main shaft compared to baseline concentrations, and the temporal variations are reduced compared to those observed in WR 15-18. These WRs roughly correspond to the conglomerate, weathered granite, and LAFZ, which have large inflow volumes (Fig. 2). Cl concentration in WR 15-18 tends to increase with time (Fig. 4), which is possibly due to upconing of relatively $\mathrm{Cl}$ rich water from depth. The change of $\mathrm{Cl}$ concentration in WR 19 and 20 is small and represents the LSFD. At sites 
Fig. 3 Water pressures in monitoring boreholes during facility construction and operation

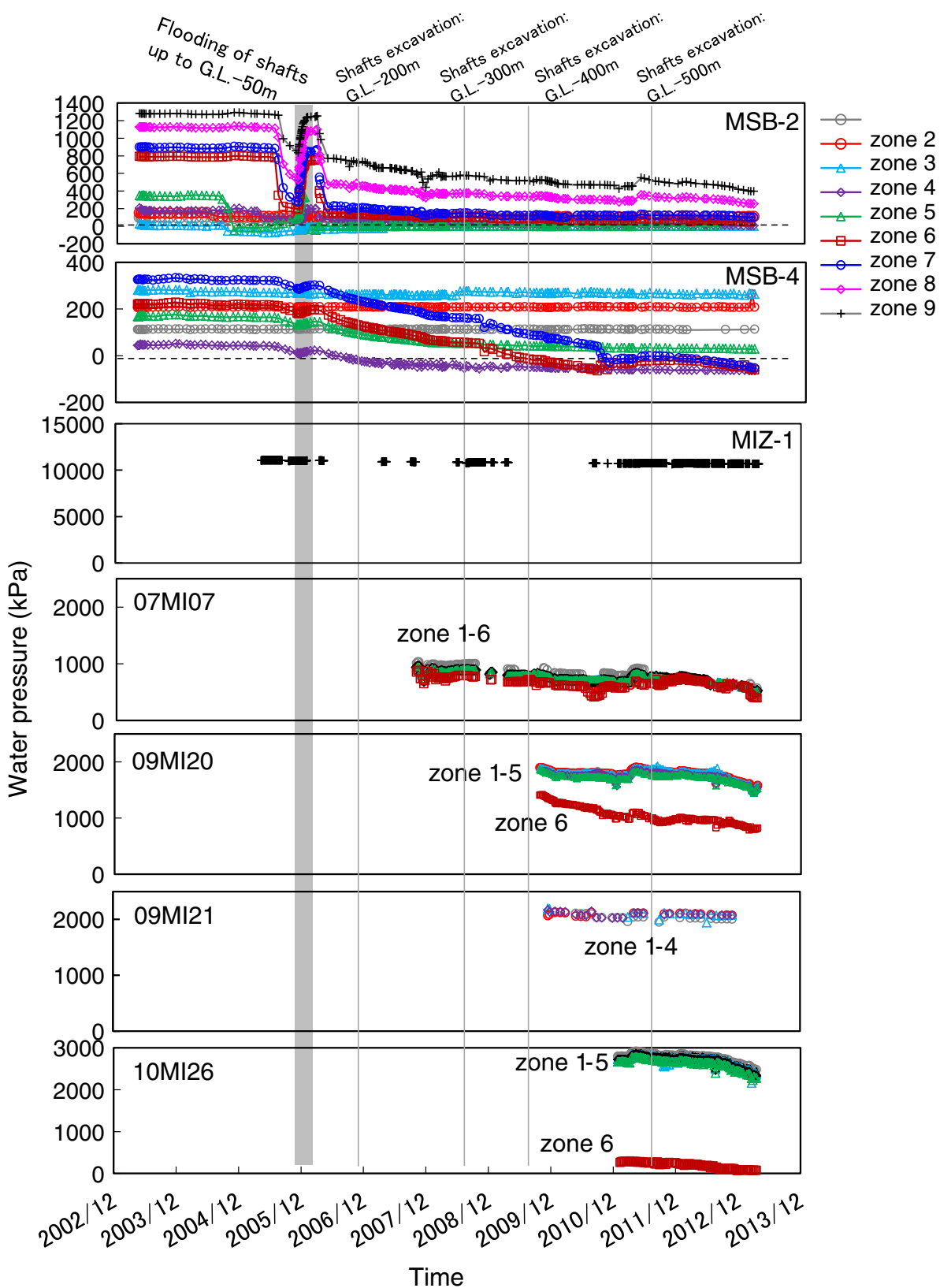

deeper than WR 10 of the ventilation shaft, Cl concentrations are higher than those in WRs at similar depths of the main shaft (Fig. 4). The magnitude of upconing around the ventilation shaft could be larger than around the main shaft, which is associated with an increased volume of water inflow into the ventilation shaft (Fig. 2). Cl concentrations in these WRs increased during the initial observation period but subsequently decreased with time. The WRs were sequentially installed in the deepest part of the shaft as the excavation progressed, and therefore, the observation at each WR is affected by upconing in the initial period. Increase in $\mathrm{Cl}$ concentrations from baseline levels due to upconing is observed to be in the order of several tens to hundreds $\mathrm{mg}^{-1}$ in the ventilation shaft. Groundwater movement by upconing is illustrated using these groundwater chemistry data. For example, $\mathrm{Cl}$ concentration at WR 13 (300 m depth) in the ventilation shaft was approximately $250 \mathrm{mg} 1^{-1}$ during upconing periods (December 2009; Fig. 4). This value corresponds to $\mathrm{Cl}$ concentrations observed at approximately $450 \mathrm{~m}$ depth prior to shaft excavation. It implies that groundwater from approximately $150 \mathrm{~m}$ below moved upward to the bottom of the shaft. As excavation of the shaft advances to deeper depths, the upconing point moves to deeper depths. Meanwhile, in the upper depths, upconing is reduced and the impact of shallow groundwater infiltration increases with time. The shallow groundwater with comparatively lower $\mathrm{Cl}$ concentrations infiltrates to depth around the 
Fig. 4 Chloride concentration at water collection rings during facility construction and operation
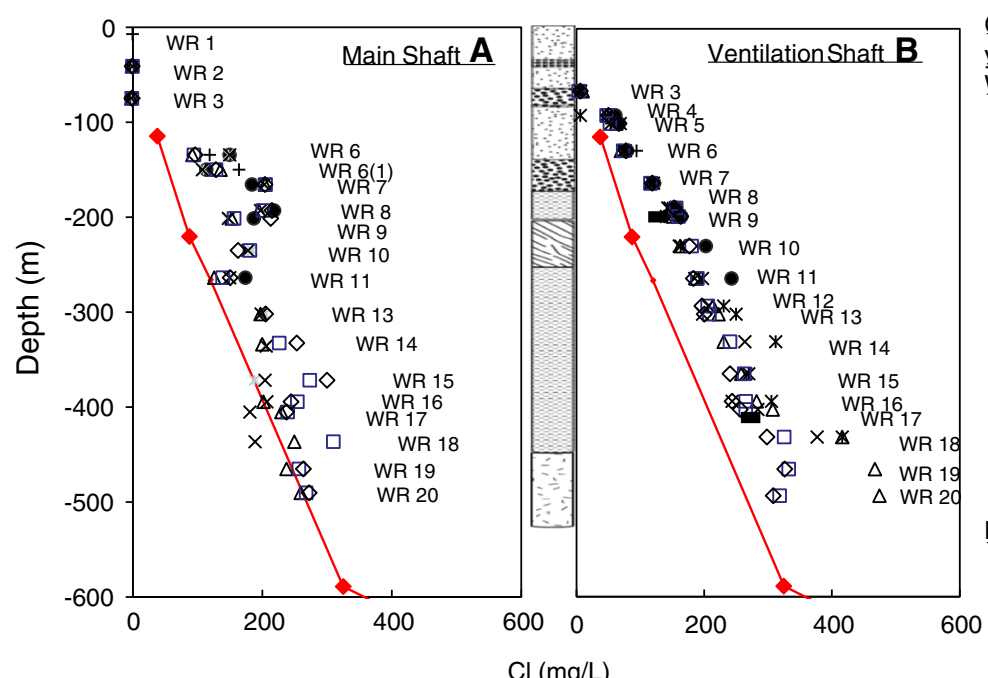

Chemical change over the years at each depth of Water collection rings

+ Dec. 2007

- Dec. 2008

* Dec. 2009

× Dec. 2010

$\Delta$ Dec. 2011

Dec. 2012

$\diamond$ Mar. 2013

Baseline condition

$\longrightarrow$ MIZ-1 (before shaft excavation)

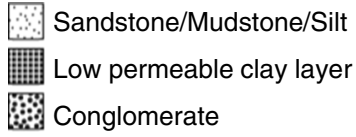

Granite(UHFD)

Tranite(LAFZ) Granite(LSFD) ventilation shaft and dilutes the salinity of infiltrating groundwater. In contrast, the influence of the upconing and subsequent shallower groundwater infiltration appears to be suppressed around the main shaft by the presence of a lowpermeability altered fracture zone located around the MSF. One finding is that the extent of hydrochemical disturbances resulting from the MIU facility construction and operation depends on the distribution of hydrogeological structures such as these low-permeability clay layers, conglomerates, and faults.

\section{Trends in groundwater hydrochemistry}

\section{Monitoring boreholes at the surface}

Figure 5 shows groundwater chemistry trends in all monitoring boreholes drilled from surface. Water-mineral interactions occur between the groundwater derived from deeper or shallower depths and fracture surface minerals including fresh minerals in newly created flow paths by excavation and engineering materials such as cement. Nevertheless, chemical components which vary with $\mathrm{Cl}$ concentrations are largely due to the mixing process of groundwaters with distinct salinity. The correlations between concentrations of $\mathrm{Cl}$ and other elements are shown in the Online Resource 1.

$\mathrm{Cl}$ concentration in MSB boreholes is variable due to the presence of clay layers (Table 1; Fig. 5). However, the hydrochemical influence of the facility construction is likely to extend deeper than low-permeability clay layers. At site MSB-2, Ca, DIC, and $\mathrm{SO}_{4}$ concentrations fluctuate throughout zone 1 (Fig. 5). Because MSB-2 is located in the developed land for the MIU facility construction, the variations of $\mathrm{Ca}$, DIC, and $\mathrm{SO}_{4}$ concentrations in zones 1 likely occur because of the weathering of sulfate and carbonate minerals in shallow horizons (Iwatsuki et al. 2005). Groundwater chemistry of zones 8 and 9 observed in the early observations is similar to those of zones 1 and 2 in shallow sedimentary rock, which subsequently changed the chemistry in deep sedimentary rocks (e.g., zones 6 and 7; Fig. 5 and Online Resource 1). This is because the shallow groundwater contamination in these relatively permeable basal conglomerates and weathered granites, which occurred during borehole drilling and installation of the groundwater monitoring system, is eliminated over time with long-term groundwater sampling. During shaft flooding between October 2005 and February 2006, associated changes in elemental concentrations were observed in zones $4-9$ because of reverse infiltration of groundwater flooding in the shafts. The flood water is likely to be derived from the basal conglomerate (WR-7: Fig. 2), which corresponds to zone 7 and 8 of MSB-2 (Fig. 1). Groundwater chemistry in zone 4, 6, 8 , and 9 of MSB-2 tends to approach that of zone 7 . The correlations among $\mathrm{Cl}$ concentration and other chemical components are not obvious in MSB-2 because shaft flooding possibly caused the mixing of more than two endmember groundwaters (Online Resource 1).

In the MSB-4, $\mathrm{Na}, \mathrm{Ca}$, and $\mathrm{Cl}$ concentrations increase and DIC concentrations decrease in zones 5 and 6 (Toki Lignite-bearing Fm) with time regardless of shaft flooding. The change in zone 4 shows a inverse tendency in comparison with zone 5 and 6 (Fig. 5). Na, $\mathrm{Ca}$, and $\mathrm{Cl}$ concentrations in these zones are positively correlated, whereas $\mathrm{DIC}, \mathrm{SO}_{4}$, and $\mathrm{Cl}$ concentrations are slightly 


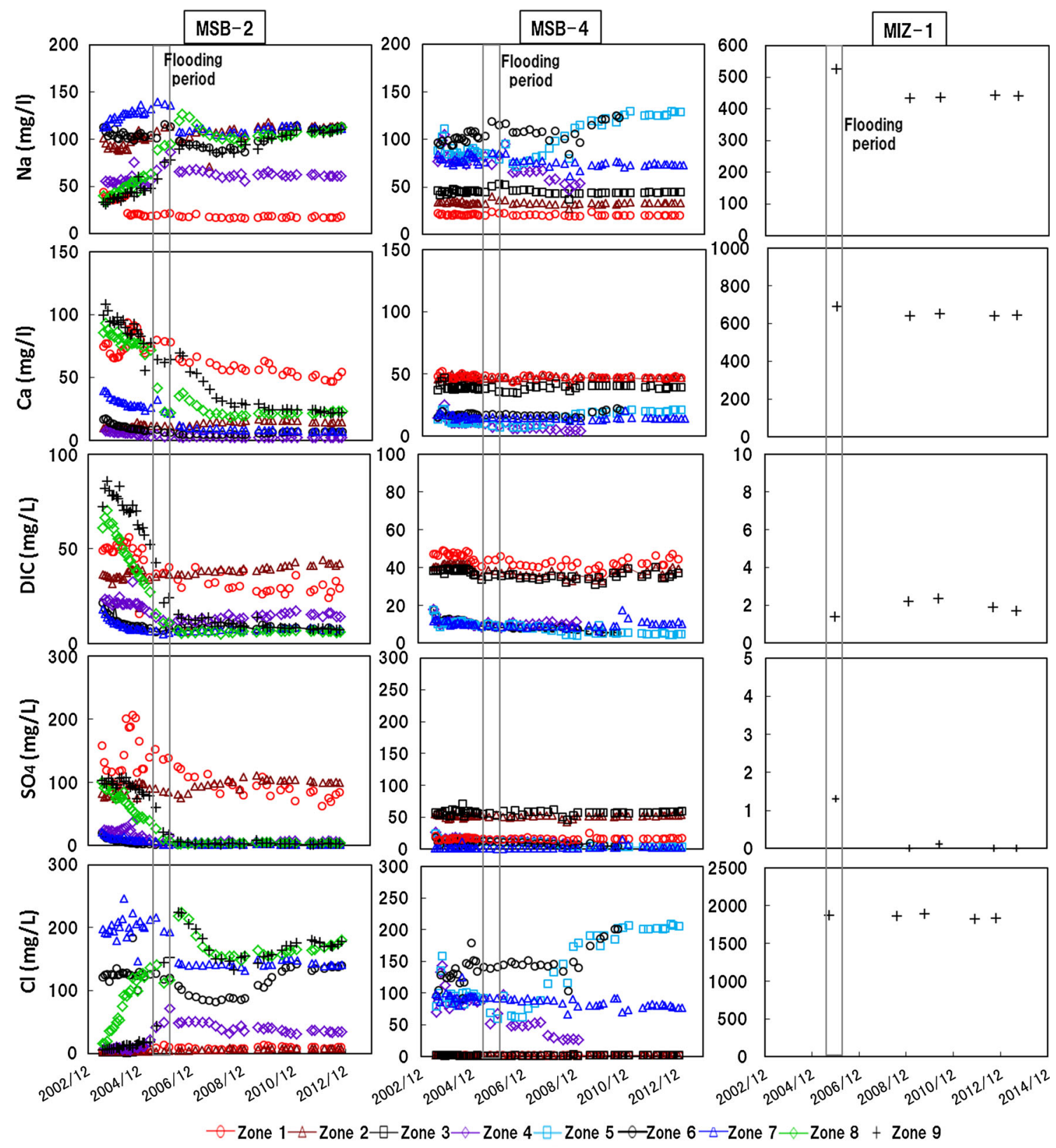

Groundwater in zone 3 and 5 of MSB-2 depleted in early monitoring.

Fig. 5 Hydrochemical changes of groundwater in MSB-2, 4 and MIZ-1

negatively correlated (Online Resource 1). The chemical variation in these zones predominantly occurs by mixing between high and low-salinity waters. The groundwater end-members are either waters of relatively low-salinity or upconed high-salinity deep water, which also has high $\mathrm{Na}$, $\mathrm{Ca}, \mathrm{Cl}$, and low $\mathrm{DIC}, \mathrm{SO}_{4}$ concentrations. The mixing ratio of the high-salinity deep water probably increases with time in zones 5 and 6 . In contrast, the mixing ratio of the low-salinity water increases with time in zone 4. $\mathrm{Na}, \mathrm{Ca}$, and $\mathrm{Cl}$ concentrations in zone 7 are lower than those in zones 5 and 6 . Here, the groundwater in zones 5 and 6 is inferred to mix with the high-salinity water derived laterally along the conglomerate layer. Further investigation is necessary with respect to the origin of this high-salinity water and its flow path. Evidences of hydrochemical disturbance are not observed in zone 9 (1149 $\mathrm{m}$ depth) in borehole MIZ-1.

\section{Monitoring boreholes in the gallery}

Groundwater chemistry was monitored from horizontal boreholes (07MI07, 09MI20, 09MI21, 10MI26, 12MI33, 


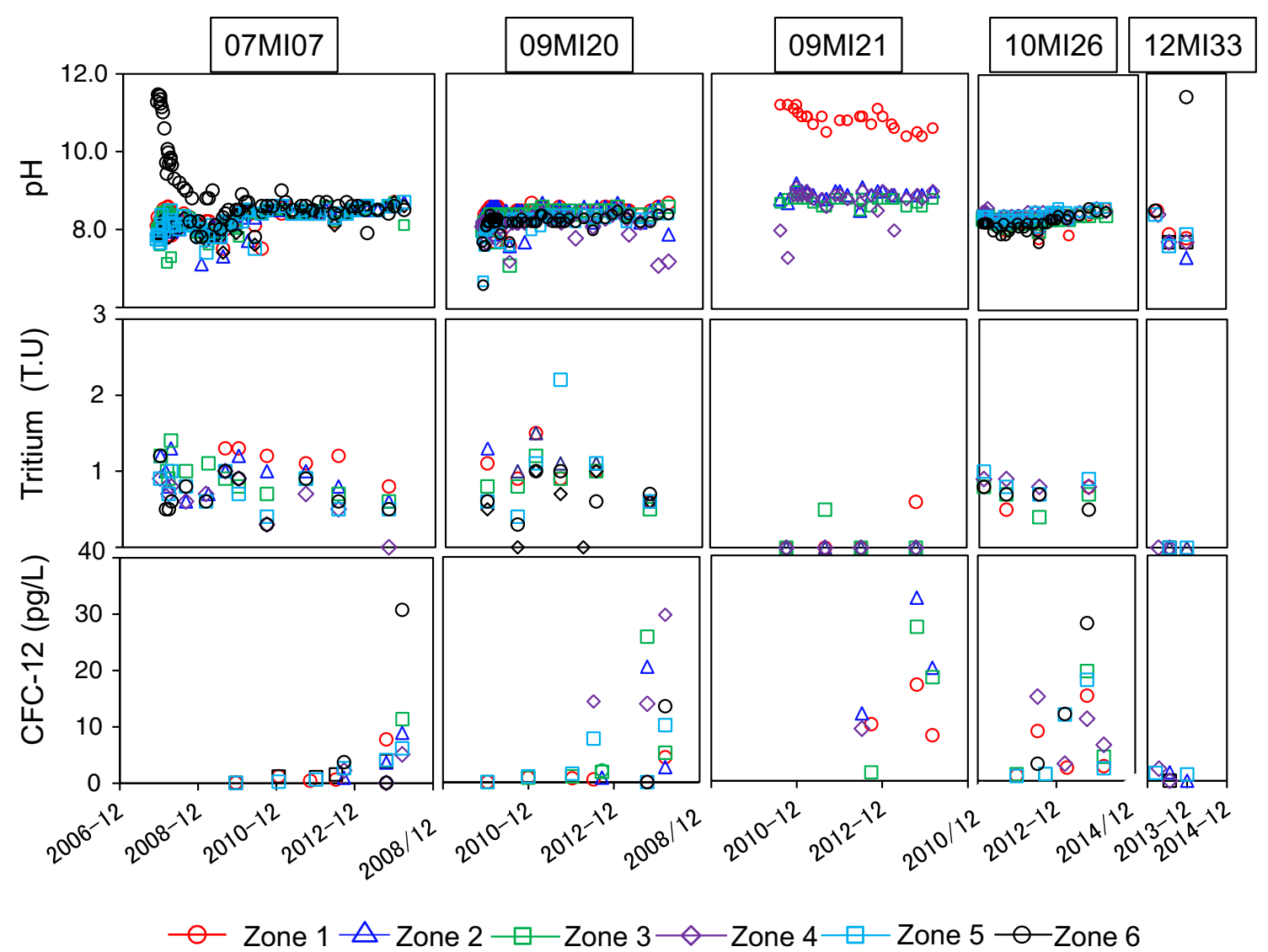

Fig. $6 \mathrm{pH}$, tritium, and $\mathrm{CFC}-12$ concentration of groundwater in the galleries

shown in Figs. 6, 7 and Online Resource 1) drilled from sub stages and galleries.

The boreholes were drilled horizontally from galleries to monitor the lateral trends in groundwater hydrochemistry. The groundwater in zone 6 of boreholes 07MI07 and 12MI33 and zone 1 of borehole 09MI21 has a high $\mathrm{pH}$ (Fig. 6) due to water-cement interactions at the borehole collar. The $\mathrm{Ca}$ and DIC concentrations are variable, regardless of the mixing process operating in these zones (Online Resource 1). Conversely, there is no alkalization of groundwater in zone 6 of 09MI20 and 10MI26. Alteration by cement materials around EDZ appears to depend on inflow, replacing alkalized groundwater behind the gallery wall with fresh groundwater. The influence of materials used in the facility construction on groundwater hydrochemistry is possibly limited to the small inflow region. These changes around EDZ will become significant due to changes in groundwater residence times once the facility closes. The observation and analysis of groundwater chemistry around a closed drift scenario will be the focus of future research.

In borehole 07MI07 at $200 \mathrm{~m}$ depth and 09MI20 at $300 \mathrm{~m}$ depth, groundwater initially had relatively high $\mathrm{Na}$, $\mathrm{Ca}, \mathrm{Cl}$ and low DIC and $\mathrm{SO}_{4}$ concentrations, which have subsequently changed to relatively low $\mathrm{Na}, \mathrm{Ca}, \mathrm{Cl}$ and high DIC, $\mathrm{SO}_{4}$ concentrations (Fig. 7). This tendency is clearly observed near the borehole collars in the excavations (e.g., zone 5 and 6). The groundwater in borehole $10 \mathrm{MI} 26$ (400 m depth) also shows a similar trend. Here, Cl, DIC, and $\mathrm{SO}_{4}$ are correlated, except in zone 1 of borehole 09MI21 (Online Resource 1). The temporal change in groundwater chemistry occurs by mixing of high- and lowsalinity waters in these monitoring boreholes.

Horizontal monitoring boreholes were sequentially drilled in the deepest gallery during excavation. Therefore, the observations at each borehole are affected by upconing during the initial period. In boreholes 07MI07, 09MI20, and 10MI26 on the south side of the MSF, groundwater with relatively high levels of $\mathrm{Na}, \mathrm{Ca}, \mathrm{Cl}$ and low DIC and $\mathrm{SO}_{4}$ concentrations during early observations is representative of the upconed water around the ventilation shaft. Since then, relatively shallow groundwater has infiltrated to the area around the ventilation shaft and is characterized by low levels of $\mathrm{Na}, \mathrm{Ca}$, and $\mathrm{Cl}$, and high DIC and $\mathrm{SO}_{4}$ concentrations. This process of groundwater replacement is most likely occurring at a faster rate on the south side of the MSF than those on the north side of the fault, reflecting the extent of hydraulic impact (i.e., drawdown of the 


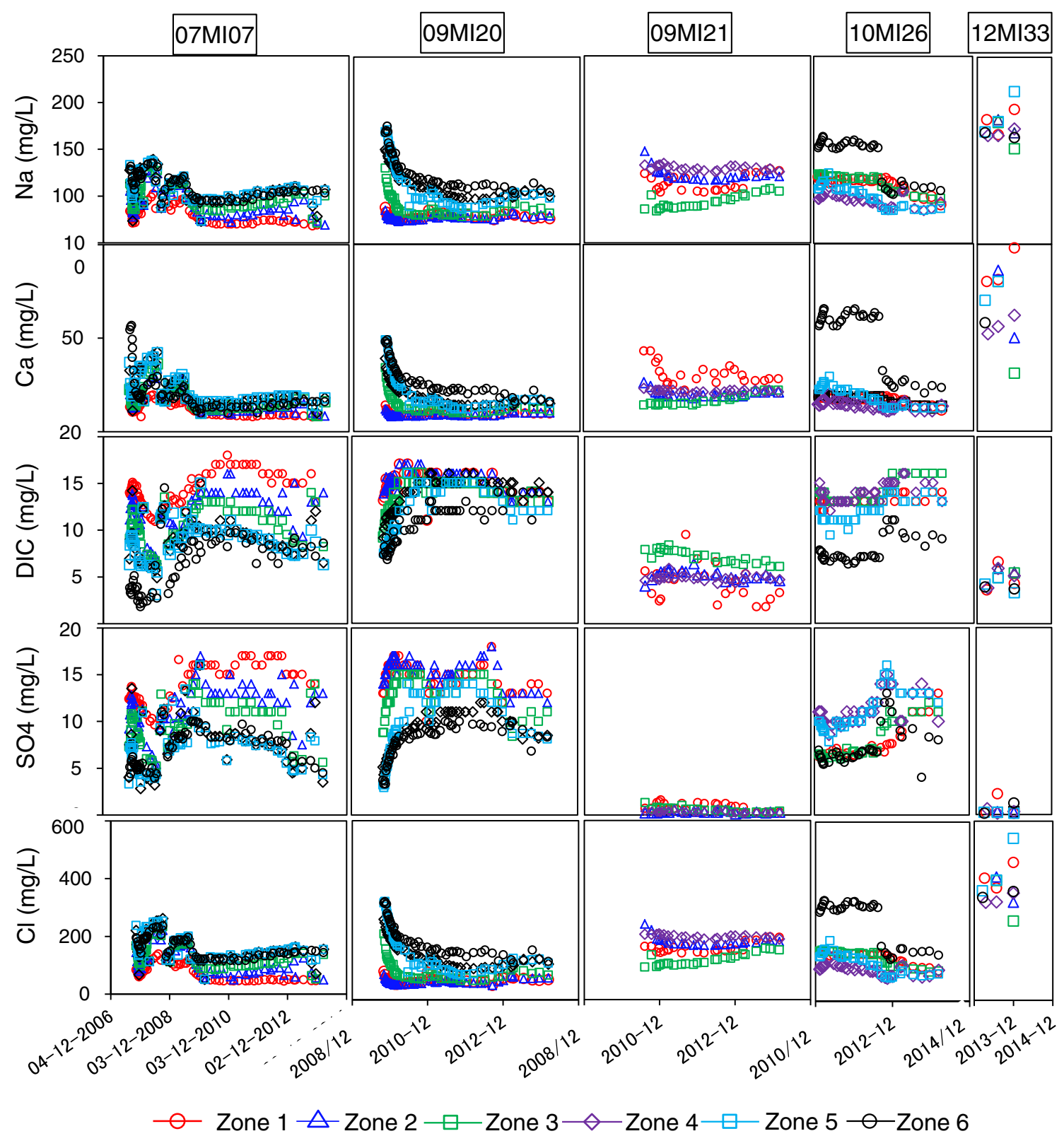

Fig. 7 Hydrochemical changes of groundwater in the galleries

groundwater level, as shown in Fig. 3). The particularly rapid change in groundwater chemistry observed in zone 6 of 10MI26 in 2012 demonstrated the replacement of relatively low-salinity groundwater due to upconing. However, such trends are not observed in borehole 09MI21 on the north side of the MSF.

Borehole 09MI21 is located approximately $100 \mathrm{~m}$ north of the MSF and was drilled into LSFD. Hydrochemical changes in the groundwater here are most likely caused by mixing with groundwaters at $300 \mathrm{~m}$ depth without being influenced by the upconing along the shaft. In general, mixing with shallower groundwater becomes the dominant process on the south side of the MSF, whereas mixing with deeper groundwater dominates groundwater chemistry on the north side of the fault. In the deepest borehole (12MI33) on the north side of the MSF, levels of $\mathrm{Na}, \mathrm{Ca}$, and $\mathrm{Cl}$ increase with time as a result of upconing.

The increase in $\mathrm{Cl}$ due to upconing during the early stages of the excavation precludes its use as an index of salinity dilution by shallow groundwater infiltration. To infer the infiltration of shallow groundwater as a result of the longterm drawdown into the shafts, observations of tritium and chlorofluorocarbons (CFCs) concentrations are used as an index of surface water infiltration (Fig. 6). Tritium is detected at several monitoring zones even though concentrations drop to zero around $200 \mathrm{~m}$ depth prior to shaft 
excavations (Iwatsuki et al. 2005). CFC-12 was first detected in 2010, and the concentrations gradually increased with time as observed in boreholes 07MI07 (200 m depth), 09MI20 and 09MI21 (300 m depth), and 10MI26 (400 m depth). This implies that surface water containing CFC-12 penetrated up to $400 \mathrm{~m}$ depth within a few years. CFC-12 concentration in surface water at the MIU site is approximately $220 \mathrm{pg} / \mathrm{kg}$. The contamination of surface water in groundwater is estimated to be approximately $6 \%$ on the basis of a comparison of CFC-12 concentrations in surface water and groundwaters. In addition, CFC-12 concentrations in zones 4 and 5 in borehole 09MI20, zones 1, 2 and, 4 in borehole 09MI21, and zones 1 and 4 in borehole $10 \mathrm{MI} 26$ are higher than those in the shallower borehole 07MI07. It can be assumed that surface water has directly penetrated to these depths via fracture zones or faults. It is difficult to estimate the continuity and connectivity of water-conducting features only on the basis of borehole investigations and geological observations of the gallery walls. Long-term monitoring of CFC concentrations will provide further insight into the hydrogeological properties of fractures and faults that are intersected by monitoring boreholes and galleries.

\section{End-member mixing}

As described previously, $\mathrm{Cl}$ concentrations are correlated with other components in groundwaters below the lowpermeability clay layer. Table 2 presents the correlation coefficients for all the chemical components analyzed in these groundwater samples. All chemical components except for $\mathrm{Mg}$ and $\mathrm{Si}$ appear to correlate well with $\mathrm{Cl}$.

Principal component analysis (PCA) was performed to identify the chemical composition of groundwater endmembers using the chemical data obtained from over 1000 groundwater samples located below the low-permeability clay layer, but excluding the areas considered to have been contaminated during drilling or subsequently by cement materials (original data are provided in Online Resource 2). The variance of seven chemical components $(\mathrm{Na}, \mathrm{K}, \mathrm{Ca}$, DIC, $\mathrm{SO}_{4}, \mathrm{~F}$, and $\mathrm{Cl}$ ) was analyzed by PCA. The loadings were evaluated to determine the chemical components responsible for the observed correlations. The chemical components with the largest positive and negative loadings make the biggest contribution (Farnham et al. 2003). The first principal component (PC 1) and second principal component (PC 2) values of groundwaters are shown in Online Resource 3. PC 1 is dominated by $\mathrm{Na}, \mathrm{Ca}$, and $\mathrm{Cl}$ concentrations, and PC 2 is dominated by DIC, $\mathrm{SO}_{4}$, and $\mathrm{F}$ concentrations. Almost all the groundwater data plot in the area is surrounded by following end-members: (A) MIZ-1 (1150 m), (B) 09MI21 (300 m), and (C) 07MI07 (200 m).

The chemical composition of all end-members is shown in Table 3. The groundwater in borehole MIZ-1 prior to facility construction plots on $\mathrm{A}-\mathrm{B}^{\prime}$ (MIZ-1-220 m)-C' (MIZ-1-115 m) lines. Owing to the lack of data around $300 \mathrm{~m}$ depth of MIZ-1, the PCs are not identified for groundwater at this depth prior to facility construction. Even so, the data from depths of $650 \mathrm{~m}$ (MIZ-1) and $500 \mathrm{~m}$ (12MI33) plot near the A-B ( $\left.\mathrm{B}^{\prime}\right)$ lines, which would imply the salinity depth profile from 300 to $1150 \mathrm{~m}$.

If the groundwater mixing occurred vertically, $\mathrm{PC}$ values would plot along the $\mathrm{A}-\mathrm{B}\left(\mathrm{B}^{\prime}\right)$ lines. The $\mathrm{PC}$ values of zone 3 in borehole $09 \mathrm{MI} 21$ on the north side of the MSF plot toward A along the A-B line, indicating that the mixing proportion of relatively deep groundwater increases over time. The variability in PCs of zone 2 and 4 is relatively small compared to that of zone 3 because the connectivity and continuity of fractures in zone 3 may be larger than those in zone 2 and 4. The PCs of zone 5 and 6 of borehole MSB-4 plots around A-B ( $\left.\mathrm{B}^{\prime}\right)$ lines. These zones are likely to be connected to the WRs in the conglomerate (WR 7), which showed the largest water inflow. The relatively deep groundwaters in the granite might be drawing to WR 7 via these conglomerates.

The PC values of boreholes 09MI20 and 10MI26 with time tend to plot toward end-member $\mathrm{C}$ regardless of $\mathrm{A}-\mathrm{B}$ $\left(\mathrm{B}^{\prime}\right)$ lines. The groundwater in the depths of 300-400 $\mathrm{m}$ on the south side of the MSF is diluted with time due to mixing with waters of similar chemical composition to end-member $\mathrm{C}$. The PC values of borehole 07MI07 plot
Table 2 Correlation factor among chemical components in monitoring boreholes

\begin{tabular}{|c|c|c|c|c|c|c|c|c|c|}
\hline & $\mathrm{Na}$ & $\mathrm{K}$ & $\mathrm{Ca}$ & $\mathrm{Mg}$ & DIC & S04 & $\mathrm{F}$ & $\mathrm{Cl}$ & $\mathrm{Si}$ \\
\hline $\mathrm{Na}$ & 1.00 & & & & & & & & \\
\hline $\mathrm{K}$ & 0.65 & 1.00 & & & & & & & \\
\hline $\mathrm{Ca}$ & 0.82 & 0.65 & 1.00 & & & & & & \\
\hline $\mathrm{Mg}$ & 0.49 & 0.58 & 0.26 & 1.00 & & & & & \\
\hline DIC & -0.53 & -0.28 & -0.31 & 0.05 & 1.00 & & & & \\
\hline S04 & -0.49 & -0.21 & -0.25 & -0.14 & 0.80 & 1.00 & & & \\
\hline $\mathrm{F}$ & -0.57 & -0.36 & -0.39 & -0.26 & 0.15 & -0.06 & 1.00 & & \\
\hline $\mathrm{Cl}$ & 0.95 & 0.68 & 0.95 & 0.36 & -0.50 & -0.44 & -0.49 & 1.00 & \\
\hline $\mathrm{Si}$ & -0.06 & 0.25 & 0.05 & 0.03 & 0.07 & 0.16 & -0.09 & -0.01 & 1.00 \\
\hline
\end{tabular}


Table 3 Chemical compositions of end-member water

\begin{tabular}{|c|c|c|c|c|c|c|c|c|c|c|c|}
\hline & Borehole/Zone No. (depth) & Sampling date & $\begin{array}{l}\mathrm{pH} \\
-\end{array}$ & $\begin{array}{l}\mathrm{EC} \\
\mathrm{mS} / \mathrm{m}\end{array}$ & $\begin{array}{l}\mathrm{Na}^{+} \\
\mathrm{mg} / \mathrm{L}\end{array}$ & $\begin{array}{l}\mathrm{K}^{+} \\
\mathrm{mg} / \mathrm{L}\end{array}$ & $\begin{array}{l}\mathrm{Ca}^{2+} \\
\mathrm{mg} / \mathrm{L}\end{array}$ & $\begin{array}{l}\mathrm{Mg}^{2+} \\
\mathrm{mg} / \mathrm{L}\end{array}$ & $\begin{array}{l}\mathrm{DIC} \\
\mathrm{mg} / \mathrm{L}\end{array}$ & $\begin{array}{l}\mathrm{SO}_{4}^{2-} \\
\mathrm{mg} / \mathrm{L}\end{array}$ & $\begin{array}{l}\mathrm{S}^{2-} \\
\mathrm{mg} / \mathrm{L}\end{array}$ \\
\hline A & MIZ-1 / Zone9 (1,150 m) & $17-09-2009$ & 8.2 & 590 & 434.0 & 3.3 & 648.9 & 1.3 & 2.3 & 0.1 & $<0.1$ \\
\hline $\mathrm{B}$ & 09MI21 / Zone3 (300 m) & $14-07-2010$ & 8.7 & 50 & 86.0 & 0.3 & 14.0 & $<0.1$ & 7.9 & 1.3 & $<0.1$ \\
\hline $\mathrm{C}$ & 07MI07 / Zone1 (200 m) & 01-07-2011 & 8.5 & 38 & 70.0 & 0.3 & 8.2 & $<0.1$ & 17.0 & 17.0 & 0.5 \\
\hline $\mathrm{B}^{\prime}$ & MIZ-1 $(220 \mathrm{~m})^{\mathrm{a}}$ & 09-07-2003 & 8.9 & 48 & 68.1 & 0.9 & 11.1 & 0.1 & 6.6 & 8.4 & 4.5 \\
\hline \multirow[t]{2}{*}{$\mathrm{C}^{\prime}$} & $\operatorname{MIZ-1}(115 \mathrm{~m})^{\mathrm{a}}$ & $20-04-2003$ & 9.2 & 35 & 58.7 & 0.3 & 5.9 & 0.1 & 9.6 & 6.8 & 0.1 \\
\hline & Borehole/Zone No. (depth) & Sampling date & $\begin{array}{l}\mathrm{F}^{-} \\
\mathrm{mg} / \mathrm{L}\end{array}$ & $\begin{array}{l}\mathrm{Cl}^{-} \\
\mathrm{mg} / \mathrm{L}\end{array}$ & $\begin{array}{l}\mathrm{NO}_{3}^{-} \\
\mathrm{mg} / \mathrm{L}\end{array}$ & $\begin{array}{l}\mathrm{NO}_{2}^{-} \\
\mathrm{mg} / \mathrm{L}\end{array}$ & $\begin{array}{l}\mathrm{Si} \\
\mathrm{mg} / \mathrm{L}\end{array}$ & $\begin{array}{l}\mathrm{Al} \\
\mathrm{mg} / \mathrm{L}\end{array}$ & $\begin{array}{l}\mathrm{T}-\mathrm{Fe} \\
\mathrm{mg} / \mathrm{L}\end{array}$ & $\begin{array}{l}\mathrm{Fe}^{2+} \\
\mathrm{mg} / \mathrm{L}\end{array}$ & $\begin{array}{l}\mathrm{Mn} \\
\mathrm{mg} / \mathrm{L}\end{array}$ \\
\hline A & MIZ-1 / Zone9 (1,150 m) & $17-09-2009$ & 3.1 & 1890 & $<0.05$ & $<0.05$ & 8.9 & 0.01 & 0.024 & $<0.2$ & 0.109 \\
\hline $\mathrm{B}$ & 09MI21 / Zone3 (300 m) & $14-07-2010$ & 13.0 & 109 & $<0.05$ & $<0.05$ & 6.9 & 0.06 & 0.075 & $<0.2$ & 0.004 \\
\hline $\mathrm{C}$ & 07MI07 / Zone1 (200 m) & 01-07-2011 & 8.4 & 45 & $<0.05$ & $<0.05$ & 7.1 & $<0.01$ & $<0.005$ & $<0.2$ & $<0.003$ \\
\hline $\mathrm{B}^{\prime}$ & $\operatorname{MIZ-1}(220 \mathrm{~m})^{\mathrm{a}}$ & 09-07-2003 & 11.9 & 85 & $<0.2$ & $<0.3$ & 4.5 & 0.89 & 0.086 & $<0.05$ & 0.084 \\
\hline $\mathrm{C}^{\prime}$ & $\operatorname{MIZ-1}(115 \mathrm{~m})^{\mathrm{a}}$ & $20-04-2003$ & 8.7 & 38 & $<0.2$ & $<0.3$ & 8.6 & 0.06 & 0.021 & $<0.05$ & 0.002 \\
\hline
\end{tabular}

${ }^{a}$ Iwatsuki et al. (2005)

close to end-member $\mathrm{C}$ during the early period of observation, but approach $\mathrm{A}-\mathrm{B}\left(\mathrm{B}^{\prime}\right)$ lines in more recent observations. The cause of this variation is unclear, but the groundwater in borehole $07 \mathrm{MI} 07$ is likely to be derived from the conglomerates in sedimentary rocks.

Owing to the large volume of groundwater inflow into the ventilation shaft, low-salinity water with similar chemistry to end-member $\mathrm{C}$ is drawn into depths of 300-400 m over time. The chemical composition of endmember $\mathrm{C}$ is different to baseline groundwater chemistry in granite, as estimated by MIZ-1 data and in sedimentary rock (MSB-4). The origin of end-member $\mathrm{C}$ is currently unknown, though it expected that the groundwater chemistry at $300-400 \mathrm{~m}$ depth on the south side of the MSF will gradually become similar to that of end-member $\mathrm{C}$ if the current facility operation continues into the future.

Groundwater chemistry in borehole 09MI21 drilled in LSFD on the north side of the MSF is less than boreholes 07MI07, 09MI20, 10MI26, which are drilled in UHFD on the south side of the MSF. The impact of facility construction and operation on groundwater chemistry and future changes is closely related with the hydrogeological structure and properties of the host rock. Suitable spatial density of monitoring stations must take into account the hydrogeological heterogeneity to estimate future long-term hydrochemical changes.

\section{Conclusions}

A continuous 10-year hydrochemical monitoring program was established during the construction and operation of the MIU facility. Observations were obtained up to a depth of $500 \mathrm{~m}$, and we found that hydrochemical changes in the granite occurred up to $100 \mathrm{~m}$ away from constructed shafts. Conversely, the chemical disturbance by materials used in the facility construction on groundwater is limited to the small inflow region around the gallery. The principal mechanisms of hydrochemical disturbances are (1) upconing of high-salinity deep groundwater around the deepest part of the shaft and gallery, and (2) infiltration of low-salinity shallow groundwater. The hydrochemical changes of groundwater differ on either sides of the MSF.

The hydraulic impact because of the construction and operation of the large underground facility depends on the 3-dimensional distribution of hydrogeological structures such as clay layers, conglomerates, faults, fracture zones, and rock mass with distinct permeability. Conceptualization of the architecture of these compartments is essential when considering the hydrochemical impacts during the planning stage of underground facilities. In this case, the presence of low-permeability hydrogeological structure such as clay layers isolates the biosphere from the underground facility, which may prevent any negative impact on water resources at surface.

Chemical disturbances occur due to changes in the mixing ratios of chemically distinct groundwaters in response to hydraulic impacts. During shaft excavation in fractured rock, groundwater pumping from a shaft causes upconing of relatively deeper groundwater around the bottom of the shaft. The deeper, upconed groundwater then resides around the shaft for several months even after shaft sinking has progressed to greater depths. The upconed groundwater is eventually replaced by shallower groundwater due to constant drainage into the shaft. Hydrochemical change of groundwater can be rapid in cases where large water inflows are expected during the excavation. 
The monitoring program, including borehole placement, should take into account the distance from the facility and the presence of potential hydrogeological compartment structures such as conglomerates, clay layers, faults, and fractured zones. In this case, the excavation disturbed the typical groundwater drawdown area to more than several hundred meters from the shaft.

To reduce the environmental impact of any underground facility, it is necessary to maintain groundwater inflow under control during construction and operation and to allow the recovery of the groundwater level by closing the facility prior to the infiltration of large volumes of shallow water. However, a seamless watertight shotcrete/concrete lining on the gallery and shaft walls to control inflow may result in an unexpected increase in inflow due to higher water pressures developing behind the wall. If this happens, effective suppression of groundwater inflow would be difficult from the viewpoint of safety. Consequently, understanding hydrogeological structures prior to facility construction and planning of shaft and gallery layouts in low-permeability rock is essential to minimize drawdown of the groundwater level and consequent hydrochemical impacts.

Future studies of hydrochemical recovery processes in a variety of hydrogeological settings and facility scales are required. These studies should also focus on impacts from artificial materials used around gallery upon groundwater residence times after facilities have closed.

Acknowledgments The authors wish to thank G. McCrank, an exJAEA International Fellow, for help with manuscript preparation and advice for this research.

Open Access This article is distributed under the terms of the Creative Commons Attribution 4.0 International License (http://creativecommons.org/licenses/by/4.0/), which permits unrestricted use, distribution, and reproduction in any medium, provided you give appropriate credit to the original author(s) and the source, provide a link to the Creative Commons license, and indicate if changes were made.

\section{References}

Banwart S, Gustafsson E (1994) Large-scale intrusion of shallowwater into a vertical fracture-zone in crystalline bedrock-initial hydrochemical perturbation during tunnel construction at the aspo-hard-rock- laboratory, Southeastern Sweden. Water Resour Res 30:1747-1763

Bauer S, Beyer C, Dethlefsen F, Dietrich P, Duttmann R, Ebert M, Feeser V, Gorke U, Köber R, Kolditz R, Rabbel W, Schanz T, Schäfer D, Würdemann H, Dahmke A (2013) Impacts of the use of the geological subsurface for energy storage: an investigation concept. Environ Earth Sci 70:3935-3943

Berner U, Kulik DA, Kosakowski G (2013) Geochemical impact of a low-pH cement liner on the near field of a repository for spent fuel and high-level radioactive waste. Phys ChemEarth 64:46-56

Bossart P, Meier PM, Moeri A, Trick T, Mayor J (2002) Geological and hydraulic characterisation of the excavation disturbed zone in the opalinus clay of the mont terri rock laboratory. Eng Geol 66:19-38
Cai M, Kaiser PK (2005) Assessment of excavation damaged zone using a micromechanics model. Tunn Undergr Space Technol 20:301-310

Cai M, Kaiser PK, Martin CD (2001) Quantification of rock mass damage in underground excavations from microseismic event monitoring. Int J Rock Mech Min Sci 38:1135-1145

Cesano D, Olofsson B, Bagtzoglou A (2000) Parameters regulating groundwater inflows into hard rock tunnels-a statistical study of the Bolmen tunnel in southern Sweden. Tunn Undergr Space Technol 15:153-165

Daimaru S, Takeuchi R, Takeda M, Ishibashi M (2010) Hydrogeological characterization based on long term groundwater pressure monitoring. In: Proceedings of 13th international conference on environmental remediation and radioactive waste management (ASME 2010):149-158

Domènech C, Arcos D, Duro L (2006) Effect of the mineral precipitation- dissolution at tunnel walls during the operational and post-operational phases. SKB Report R-06-108, ISSN 1402-3091

Farnham IM, Johannesson KH, Singh AK, Hodge VF, Stetzenbach KJ (2003) Factor analytical approaches for evaluating groundwater trace element chemistry data. Anal Chim Acta 490:123-138

Flint A, Flint L, Kwicklis E, Bodvarsson G, Fabryka-Martin J (2001) Hydrology of Yucca Mountain, Nevada. Rev Geophys 39:447-470

Font-Capo J, Vazquez-Sune E, Carrera J, Herms I (2012) Groundwater characterization of a heterogeneous granitic rock massif for shallow tunneling. Geologica Acta 10:395-408

Gascoyne M, Gascoyne S, Sargent FP (1995) Geochemical influences on the design, construction and operation of a nuclear waste vault. Appl Geochem 10:657-671

Grenier C, Bernard-Michel G, Benabderrahmane H (2009) Evaluation of retention properties of a semi-synthetic fractured block from modelling at performance assessment time scales (Äspö Hard Rock Laboratory, Sweden). Hydrogeol J 17:1051-1066

Ii H, Kagami H (1997) Groundwater level and chemistry changes resulting from tunnel construction near Matsumoto City, Japan. Environ Geol 31:76-84

Iwatsuki T, Furue R, Mie H, Ioka S, Mizuno T (2005) Hydrochemical baseline condition of groundwater at the Mizunami underground research laboratory (MIU). Appl Geochem 20:2283-2302

Joyce S, Hoek J, Serco LH (2010) SR-Site Pre-modelling: Sensitivity studies of hydrogeological model variants for the Laxemar site using CONNECTFLOW. SKB Technical Report R-08-108, Svensk Kärnbränslehantering $\mathrm{AB}$

Kosakowski G, Berner U (2013) The evolution of clay rock/cement interfaces in a cementitious repository for low- and intermediate level radioactive waste. Phys Chem Earth 64:65-86

Kumazaki N, Ikeda K, Goto J, Mukai K, Iwatsuki T, Furue T (2003) Synthesis of the shallow borehole investigations at the MIU construction site. JNC TN7400 2003-005. Japan Nuclear Cycle Development Institute

Laaksoharju M, Tullborg E, Wikberg P, Wallin B, Smellie J (1999) Hydrogeochemical conditions and evolution at the Aspo HRL, Sweden. Appl Geochem 14:835-859

Lee J, Kim RH, Chang HW (2003) Interaction between groundwater quality and hydraulic head in an area around an underground LPG storage cavern, Korea. Environ Geol 43:901-912

Lee E, Lim JW, Moon HS, Lee KK (2014) Assessment of seawater intrusion into underground oil storage cavern and prediction of its sustainability. Environ Earth Sci. doi:10.1007/s12665-0143473-5

Maejima T, Morioka H, Mori T, Aoki K (2003) Evaluation of loosened zones on excavation of a large underground rock cavern and application of observational construction techniques. Tunn Undergr Sp Technol 18:223-232 
Mahara Y, Igarashi T, Hasegawa T, Miyakawa K, Tanaka Y, Kiho K (2001) Dynamic changes in hydrogeochemical conditions caused by tunnel excavation at the Aspo Hard Rock Laboratory (HRL), Sweden. Appl Geochem 16:291-315

Martinez-Landa L, Carrera J (2005) An analysis of hydraulic conductivity scale effects in granite (full-scale engineered barrier experiment (FEBEX), Grimsel, Switzerland). Water Resour Res 41:1-13

Martinez-Landa L, Carrera J (2006) A methodology to interpret crosshole tests in a granite block. J Hydrol 325:222-240

Marty NCM, Tournassat C, Burnol A, Giffaut E, Gaucher EC (2009) Influence of reaction kinetics and mesh refinement on the numerical modelling of concrete/clay interactions. J Hydrol 364:58-72

Metcalfe R, Hama K, Amano K, Iwatsuki T, Saegusa H (2003) Geochemical approaches to understanding a deep groundwater flow system in the Tono area, Gifu-ken, Japan. In: Nishigaki and Komatsu (eds.), Groundwater Engineering, A.A. Balkema Publishers, pp 555-561

Ohyama T, Saegusa H, Onoe H, Guimera J, White MJ, Robinson P (2008) GEOMASS: The application to characterizations of groundwater flow in the Mizunami Underground Research Laboratory project in Tono area. In: Proceedings of 36th IAH congress, CD-ROM

Olsson OL, Winberg A (1996) Current understanding of extent and properties of the excavation disturbed zone and its dependence of excavation method. In: Martino JB, Martin CD (Eds.), Proc. International Conference on Deep Geological Disposal of Radioactive Waste 101-112

Onoe H, Takeuchi R, Saegusa H, Daimaru S, Karino T (2011) Interpretation of Hydrogeological Characteristics based on Data from Long-Term Cross-Hole Pumping Test. 19th International Conference on Nuclear Engineering, Proc. ICONE-19-43560

Priyanto DG, Dixon DA, Kim C-S, Korkeakoski P, Villagran JE (2014) Preliminary modelling of the saturation of a full-sized clay and concrete shaft seal. Geological Society, London, Special Publications. doi:10.1144/SP400.38

Saegusa H, Matsuoka T (2010) Final report on the surface-based investigation phase (Phase I) at the Mizunami Underground Research Laboratory Project. JAEA-Research 2010-067. Japan Atomic Energy Agency

Saegusa H, Inaba K, Maeda K, Nakano K, McCrank G (2003) Hydrogeological modeling and groundwater flow simulation for effective hydrogeological characterization in the Tono area, Gifu, Japan. In: Nishigaki, Komatsu (Eds), Groundwater Engineering, A.A. Balkema Publishers, pp 563-569

Sasao E, Ota K, Iwatsuki T, Niizato T, Arthur RC, Stenhouse MJ, Zhou W, Metcalfe R, Takase H, Mackenzie AB (2006) An overview of a natural analogue study of the Tono uranium deposit, central Japan. Geochem Explor Environ Anal 6:5-12

Sato T, Kikuchi T, Sugihara K (2000) In situ experiments on an excavation disturbed zone induced by mechanical excavation in Neogene sedimentary rock at Tono mine, central Japan. Eng Geol 56:97-108

Shimono M, Suzuki S, Taguchi Y, Kamemura K, Sato T, Mikake S (2004) Risk assessment approach for underground research laboratory. In: Proceedings of ISRM international symposium: 3rd Asian rock mechanics symposium 359-365

Stober I, Bucher K (2007) Hydraulic properties of the crystalline basement. Hydrogeol J 15:213-222

Takeuchi S, Shimo M, Doughty C, Tsang C-F (2004) Identification of the Water-Conducting Features and Evaluation of Hydraulic parameters using Fluid Electric Conductivity Logging, Proc. 2nd International Symposium on Dynamics of Fluids in Fractured Rock:349-354

Thury M, Bossart P (1999) The Mont Terri rock laboratory, a new international research project in a Mesozoic shale formation, in Switzerland. Eng Geol 52:347-359

Tsang C-F, Bernier F, Davies C (2005) Geohydromechanical processes in the Excavation Damaged Zone in crystalline rock, rock salt, and indurated and plastic clays - in the context of radioactive waste disposal. Int J Rock Mech Mining Sci 42:109-125

Utada M (2003) Smectite-zeolite envelope surrounding the Tsukiyoshi uranium deposit, Central Japan: a natural analogue study. Resour Geol 53:293-304

Vales F, Nguyen Minh D, Gharbi H, Rejeb A (2004) Experimental study of the influence of the degree of saturation on physical and mechanical properties in Tournemire shale (France). Appl Clay Sci 26:197-207

Yang FR, Lee CH, Kung WJ, Yeh HF (2008) The impact of tunneling construction on the hydrogeological environment of "TsengWen Reservoir Trans basin Diversion Project" in Taiwan. Eng Geol 103:39-58

Younger PL (2000) Predicting temporal changes in total iron concentrations in groundwaters flowing from abandoned deep mines: a first approximation. J Contam Hydrol 44:47-69

Yuguchi T, Amano K, Tsuruta T, Danhara T, Nishiyama T (2011) Thermochronology and the three-dimensional cooling pattern of a granitic pluton: an example of the Toki granite, Central Japan. Contrib Miner Petrol 162:1063-1077

Yuguchi T, Tsuruta T, Hama K, Nishiyama T (2013) The spatial variation of initial $87 \mathrm{Sr} / 86 \mathrm{Sr}$ ratios in the Toki granite, Central Japan: implications for the intrusion and cooling processes of a granitic pluton. J. Miner Petrol Sci 108:1-12 